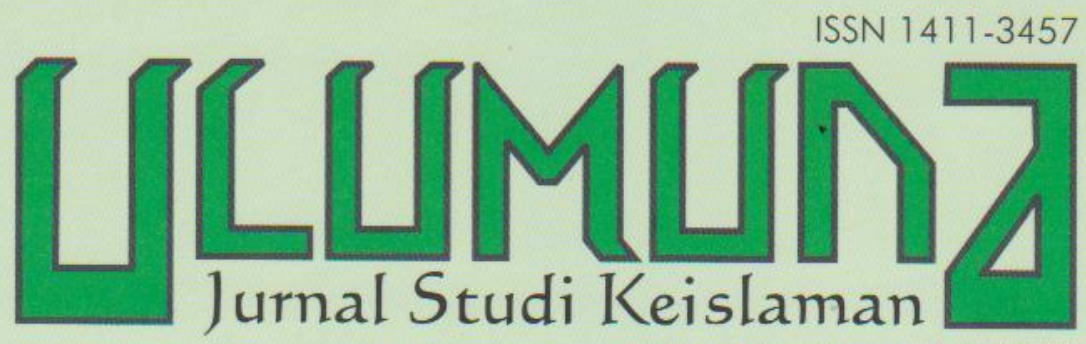

Volume XI• Nomor 1 • Juni 2007

TIELAAM - ISTORIS

PERKENBANEAN OR ENTAUSME ABAD XV-XX

Rendra khaldun

MENXBAK

KENGRASANSIMBOWK ORENTALISE

Iswaknudi

ORIENTALISME

DAN 6PAY DIALOCANTARPERADABAN

Nitivillah

MENCARIE ORENTALISME: MERETAS INAN KE ARAH

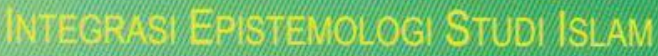
Afrizal

ORENTASM L LBERALSMEISLAM, DAN PENGENBANGAN STUD SLAMDIAIN Alwwan Fanani

MENGURA RAOKALSE ACAMA DU NDONESIA

PASCA OROE BARU Albater Merket Rout 


\section{PEDOMAN TRANSLITERASI}

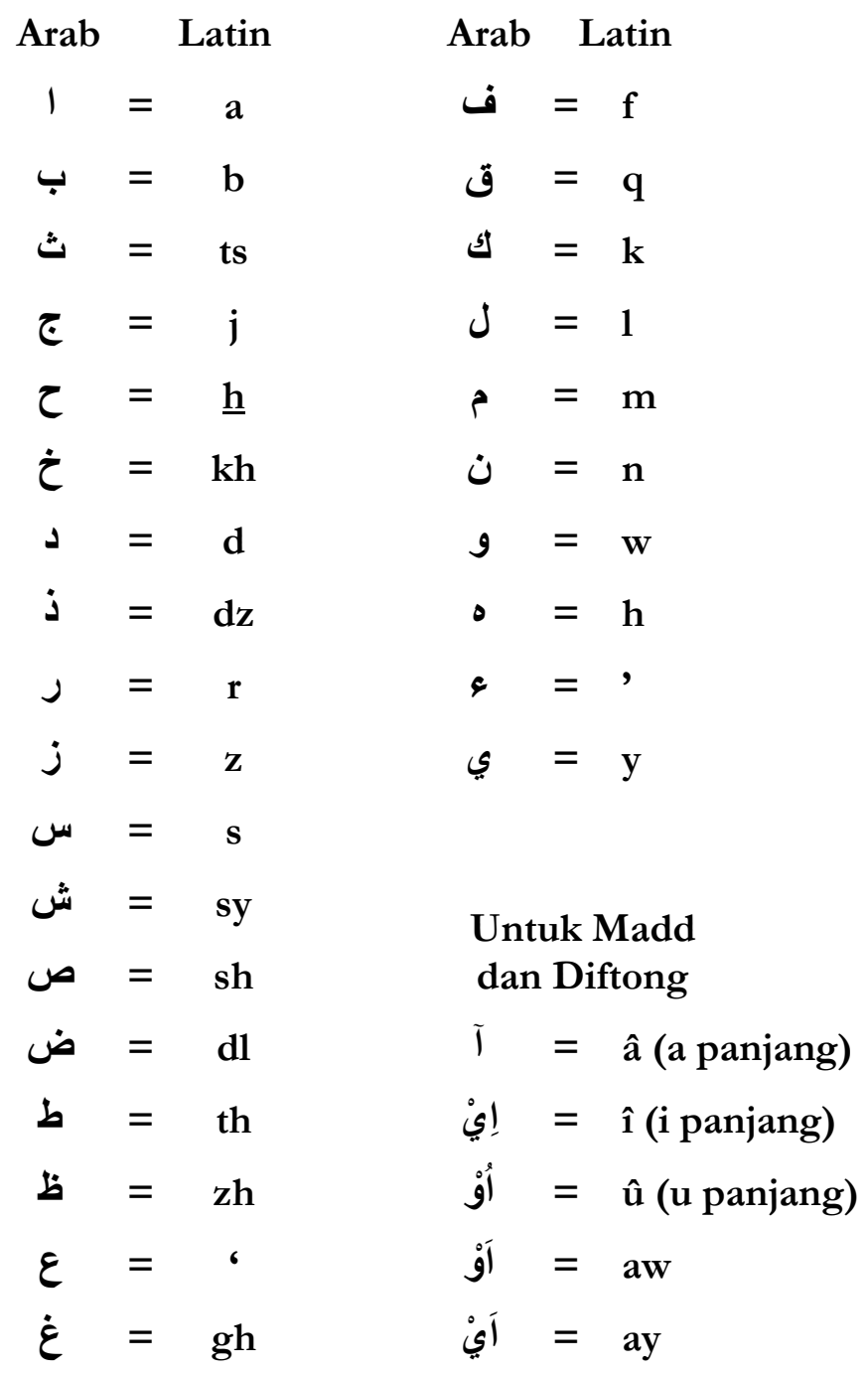


TRANSLITERASI

ANTARAN

UTAMA

Rendra Khaldun

Iswahyudi

Mutiullah

Afrizal

Ahwan Fanani

LEPAS

Miftahul Huda

Ismail Thoib

Abdul Mukti Ro'uf

Ahmad Fathan Aniq

Put

Telaah Historis Perkembangan

Orientalisme Abad XVI-XX • 1-26

Menyibak Kekerasan Simbolik

Orientalisme • 27-52

Orientalisme dan Upaya

Dialog Antarperadaban • 53-72

Mengarifi Orientalisme:

Meretas Jalan ke Arah Integrasi

Epistemologi Studi Islam • 73-92

Orientalisme, Liberalisme Islam, dan Pengembangan Studi Islam

di IAIN • 93-120

Membaca Teks Hadis: Antara Makna

Literal dan Pesan Utama • 121-140

Menggagas Reformasi Pendidikan Islam:

Telaah Filosofis Paradigmatik • 141-156

Mengurai Radikalisme Agama di Indonesia Pasca Orde Baru • 157-176

Rejection of Perda Zakat in East Lombok:

Public Criticism on Public Policy $\bullet 177$ -

198

Ulas BuKu

Fachrizal Halim Self-Criticism to Arab and Muslim

Intellectuals • 199-212

INDEKS 


\title{
MENYIBAK KEKERASAN SIMBOLIK ORIENTALISME
}

\author{
Iswahyudi*
}

\begin{abstract}
Recent order of world civilization seems to be constructed by Western civilization through project of orientalism which assumes East as the passive receiver of anything West actively offer; East is considered uncivilized, primitive, and dominated by myth and superstition. Based on the assumptions, West wants to inject modernity awareness into East cognitive sphere. But, East finds the want as a West tricky way to dominate East, a new kind of colonialism, and a hegemony.

West hegemony covered under orientalism — to use Pierre Boudeau's term -is a kind of symbolic violence. The term refers to a violence insulted smoothly; it is differed from domination which refers more to physical violence. Orientalism symbolic violence can be traced through orientalists' works on East that are scientifically and massively published. The violence should be wisely responded by East through creating balance discourse based on scientific and intuitive capabilities.
\end{abstract}

Keywords: Orientalisme, Kekerasan Simbolik, Disensus, Konsensus, Nalar.

UMAT Islam terjerumus dalam kontradiksi tak terbendung dalam menyikapi peran dan posisi Barat. Kelompok pertama dapat disebut sebagai kelompok "apologetik", suatu kelompok yang selalu membela Islam dengan argumen pembelaan diri bahwa Islam telah memuat setiap gagasan dari Barat. Mereka menolak

*Penulis adalah dosen di STAIN Ponorogo, Jawa Timur. e-mail: yudistira_2007@yahoo.com 
stigma keterbelakangan Islam. Kelompok kedua, mempertajam pembelaan Islam lebih radikal. Tidak hanya tidak mengapresiasi tetapi lebih jauh bahwa segala produk yang diusung dan ditemukan oleh orang Barat adalah "muntahan" tak berguna, bahkan bertentangan dengan Islam. Kelompok ini disebut dengan kelompok "paradoks".

Di antara dua kelompok tersebut, ada kelompok "selektif" tidak tergesa-gesa mengambil jarak. Kelompok "selektif" memposisikan pengetahuan secara netral sumber. Artinya, pengetahuan tidak harus ditelurkan dari umat Islam laiknya emas yang ditemukan dalam kotoran binatang tetap merupakan emas. Nilai dan moralitas pengetahuan itulah yang penting bukan asalusul penggagasnya.

Di pihak lain, di saat umat Islam terus mengoreksi sikap internalnya atas Barat. Barat terus menghujamkan pengetahuan tanpa lelah. Bukan saja, rasio teknokratis, meminjam Herbert Marcuse, terus menanjak dibanding dunia Timur, lebih dalam nalar eksploitatif dominatif merambah dalam nalar umat Islam. Barat mengkonstruksi nalar sekaligus menciptakan pandangan hidup dunia Timur. Barat mendorong Umat Islam teralienasi dari dirinya sendiri. Barat juga mendesak umat Islam membenci dirinya sendiri.

Oleh karena itu, hipotesis tentatif bisa mengatakan bahwa sikap "apologetik" dan "paradoks" umat Islam dapat dimengerti walaupun sikap kritis juga tidak boleh tidak dihadirkan. Dua sikap ini di samping mengkarantina umat Islam untuk tidak belajar dari orang lain, juga bisa menjadikan Islam terasing dari pergaulan dunia nyata, suatu dunia penuh pluralisme, tidak lagi, meminjam Lyotard, homologis, tetapi paralogis.

Tulisan ini dirancang untuk memberi sedikit narasi tentang kekerasan simbolik Barat atas dunia Timur melalui kajian orientalismenya. Dengan begitu, umat Islam bisa mengambil sikap yang tepat termasuk tataran aksinya. Kajian ini penting karena pertama, banyak umat Islam, dengan semangat pembelaan 
Islam, justru malah mengkerdilkan Islam; kedua, menjamurnya penentangan atas Barat tidak diimbangi dengan analisis struktur nalar yang berkembang di Barat sehingga penentangan itu tidak tepat sasaran; ketiga, banyak ditemui umat Islam yang menggeneralisasi kajian orientalisme selalu berwatak "menjajah", padahal generalisasi tersebut tidak selamanya benar; keempat, ada sebagian orang yang membela "mati-matian" apapun yang dihasilkan Barat dengan tanpa sadar ia telah terkena virus kekerasan simbolik, yaitu kekerasan wacana.

\section{Niat Hadir Orientalisme}

Orientalisme dikenal sebagai studi Islam yang dilakukan oleh orang-orang Barat. Edward W. Said menjelaskan orientalisme adalah lapangan kajian intelek. ${ }^{1}$ Pada Barat-Kristen, orientalisme dianggap mengawali eksistensi formalnya dengan Keputusan Dewan Gereja Wina tahun 1312 untuk mengajarkan bahasa Arab, Yunani, Ibrani, dan Syiria, di Paris, Oxford, Bologna, Avignon, dan Salamanca. Baginya, setiap tilikan atas orientalisme harus mempertimbangkan tidak hanya pada tokoh serta karyanya saja, tetapi juga pada lapangan kajiannya yang dilandaskan pada unit geografis, budaya, linguistik, dan etnik yang dinamakan Timur. $^{2}$

Timur yang dimaksud dari kata orientalism, sebagai objek kajian, adalah bumi belahan Timur yang membentang luas dari kawasan Timur Dekat (Turki dan sekitarnya) hingga Timur Jauh (Jepang, Korea, dan China) dan dari Asia Selatan hingga negaranegara muslim bekas Uni Soviet, serta kawasan Timur Tengah

${ }^{1}$ Eward W. Said adalah tokoh pembela Timur yang belum ada tandingannya saat ini. Ia mengurai kebobrokan orientalisme serta membongkar sisi jahat yang tak terkatakan dari orientalisme. Bukunya yang fenomenal berjudul Orientalism. Ia menjadi Guru Besar Universitas Columbia, Yew York.

${ }^{2}$ Edward W. Said, Orientalisme, ter. Asep Hikmat (Penerbit Pustaka: Bandung, 2001), 64. 
hingga Afrika Utara. ${ }^{3}$ Namun lebih spesifik, kajian orientalisme terfokus pada dunia Timur Islam termasuk Andalusia, Sisilia, dan Balkan. Timur Islam memiliki porsi penting dari orientasi Barat karena hand in hand dengan nuansa teologis Kristen pascaPerang Salib, sekaligus imperialisme atas dunia Timur yang lebih terbelakang. Dengan demikian, ada keterkaitan mapan antara glory (kejayaan), gold (kekayaan), dan gospel (keagamaan).

Mustholah Maufur mengklasifikasi munculnya orientalisme dalam beberapa niat: pertama, orientalisme memiliki kajian organis dengan penjajahan Barat di dunia Timur, khususnya Inggris dan Prancis sejak akhir abad XVIII hingga akhir Perang Dunia II. Pasca-Perang Dunia II, di bawah kendali Amerika dalam konsep neoliberalisme, niat itu terus dilanjutkan hingga sekarang. Dalam konteks ini, hampir dipastikan setiap negara imperialis memiliki kelompok sebagai think thank yang mengkaji struktur nalar maupun sosiologis negara jajahan. Belanda di Indonesia, misalnya, memiliki sosok seperti Snouck Hurgronje. ${ }^{4}$

Kedua, orientalisme menjadi kajian yang memiliki ikatan teologis dalam bungkus misionarisme. Mereka memerlukan analisis kultural yang mungkin dimasuki ajaran Kristen serta meneliti nalar Islam untuk dicari sisi lemah dari ajaran orang Timur, seperti Islam. Mencari kontradiksi ajaran adalah motivasi mereka. Niat hadir yang kedua ini terbukti dalam kasus di Indonesia bahwa agama Kristen merambah ke pelosok-pelosok kampung bersamaan dengan Portugis dan dilanjutkan Belanda selama tiga ratus tahun lebih.

${ }^{3}$ Mustolah Maufur, Orientalisme: Serbuan Ideologis dan Intelektual (Jakarta: Pustaka al-Kautsar, 1995), 11.

${ }^{4}$ Hurgronje pernah tinggal di Mekah selama waktu enam bulan antara tahun 1884 dan 1885 untuk melakukan penelitian berkaitan dengan banyaknya jamaah haji Indonesia setelah pulang dari Mekah menjadi pemimpin pemberontakan. Ia banyak memotret aktivitas jamaah haji Indonesia di Mekah. Lihat Achmad Jainuri, Ideologi Kaum Reformis (Surabaya: lpam, 2002), 24. 
Ketiga, orientalisme digunakan untuk kepentingan taktis politik Barat atas dunia Timur-Islam. Hal ini ditunjukkan dengan proyek-proyek penelitian dengan dana dari pemerintah, seperti Macdonald, orientalis Inggris yang bekerja sebagai penasehat penjajah Inggris di Anak Benua India, Hamilton Alexander Gibb, penasehat Inggris dan Amerika dalam menentukan kebijakan politik menyokong Israel dan menentang bangsa Arab, dan Louis Massignon, penasehat Prancis untuk kebijakan politik di Afrika Utara. ${ }^{5}$

Keempat, orientalisme yang sungguh-sungguh mencari informasi ilmiah secara netral. Mereka banyak membantu umat Islam memahami simpanan tradisi dalam ulasan maupun terjemahan. Maryam Jamilah menyebut tokoh ini, seperti Reynold Nicholson dan Arthur J. Arberry. ${ }^{6}$ Kelompok ini lebih senang disebut sebagai "islamisis" daripada orientalis. Di antara mereka adalah John L. Esposito, Karen Armstrong, Martin Lings, Annemarie Schimmel, John O. Voll, Ira M. Lapidus, Marshal G. Hodgson, Leonard Binder, dan Charles Kurtzman, bahkan ada yang menjadi muslim, seperti Annemarie Schimmel. Buku Ira M. Lapidus sangat monumental sehingga ia menjadi buku utama dalam kajian sejarah peradaban umat Islam di berbagai perguruan tinggi agama Islam di Indonesia. Demikian juga, Hodgson memaparkan peradaban Islam dalam sejarah secara lengkap dan sedikit memaparkan asumsi negatif.

Pemilahan semacam di atas tak terelakkan, apabila dikaitkan dengan fakta kesejarahan orientalisme yang sangat kental dengan aspek politik Barat yang memang memiliki watak menjajah, seperti keterlibatan mereka pada saat masa perang di Amerika (Gibb), Inggris (Macdonald), maupun Perancis (Massignon). Pada saat yang sama dapat dilihat karya serta analisis yang dimunculkan, seperti Ira M Lapidus. Lebih tepat yang terakhir

${ }^{5}$ Maufur, Orientalisme..., 17-8.

${ }^{6}$ Maryam Jamilah, Islam dan Orientalism: Sebuah Kajian Analitik, ter. Machnun Husein (Jakarta: Rajawali Press, 1994), 11. 
ini disebut "islamisis". Meskipun demikian, penyebutan ini tidak serta merta menghilangkan kesan sebagai pandangan orang lain atas diri umat Islam. Umat Islam harus objektif meresepsi sesuatu yang secara ilmiah terbukti benar dan bersikap kritis atas orang lain yang melihat sebagai outsider. Sadar, outsider kadang lebih berani melihat secara telanjang daripada insider yang lebih suka menutupi kekurangan dan hanya menghadirkan kelebihan.

Beberapa kalangan muslim bahkan melihat orientalisme itu hampir sepenuhnya bias kepentingan Barat yang arogan, hegemonik, dan intoleran. Pandangan semacam itu, misalnya terwakili oleh pandangan M. Amien Rais yang menghitung ada enam dogma orientalisme. Pertama, perbedaan mutlak sekaligus sistematis antara Barat yang rasional, maju, manusiawi, dan superior, dengan Timur yang sesat, irasional, terbelakang, dan inferior. Kedua, abstraksi dan teorisasi tentang Timur lebih banyak didasarkan pada teks-teks klasik daripada fakta nyata masyarakat Timur. Ketiga, Timur selalu status quo, statis, dan tidak berubah. Timur juga tidak mampu mendefinisikan dirinya. Keempat, Timur perlu ditakuti sekaligus sesuatu yang harus ditaklukkan. Kelima, al-Qur'an bukan wahyu ilahi, tetapi buku karangan Muhammad hasil kreasi dari gabungan tradisi agama Yahudi, Kristen, dan tradisi Arab pra Islam. Keenam, otentisitas semua hadis harus diragukan. ${ }^{7}$

Kecenderungan orientalisme yang hegemonik sebagaimana tergambar di atas pada gilirannya mendorong sebagaian kalangan ilmuan muslim untuk melakukan "penentangan". Minimal ada dua motif penentangan atas orientalisme, yaitu motif ideologis dan motif psikologis. Motif ideologis ditandai dengan kritik atas dominasi dan hegemoni Barat dalam struktur kolonialisme. Anwar Abdul Malik (1963) mengawali, dilanjutkan oleh Hisyam Jaid (1978), Edward W. Said (1978), dan yang paling mutakhir adalah Hassan Hanafi (1981).

7M. Amien Rais, Cakrawala Islam (Bandung: Mizan, 1986), 234. 
Said, misalnya, menjelaskan bahwa orientalisme melihat Timur sebagai penjawab pasif atas suguhan Barat, sedangkan Barat subjek yang aktif serta penentu segala sikap Timur. ${ }^{8}$ Lebih tegas, Said menyerang misi orientalisme bukan hanya misi akademis, melainkan juga memiliki akar-akar kepentingan politis, ekonomis, sekaligus religius. Secara politik, penelitian, kajian, dan pandangan Barat tentang dunia Timur bertujuan untuk kepentingan politik kolonialisme. Kolonialisme terus beriringan dengan eksploitasi sumber alam untuk dorongan ekonomi dan penyebaran agama Kristen. Kepentingan orientalisme secara implisit juga bersifat rasis, yakni penghinaan atas Dunia Timur, yang nota bene adalah dunia nonKristen. ${ }^{9}$

Hassan Hanafi, sebagaimana Said, menawarkankan proyek oksidentalisme. Baginya, oksidentalisme penting sebagai upaya menangkis serangan westernisasi yang semakin luas wilayahnya, bukan hanya pada wilayah sosial dan budaya, melainkan telah merambah ke dalam tata cara kehidupan sehari-hari. Westernisasi adalah bagian dari alienasi, yaitu saat berpindahnya subjek diri (ego, al-anâ) kepada yang lain (the other, al-âkhar). Orang yang terbaratkan adalah orang-orang yang terkontaminasi oleh ide-ide Barat, baik cara, gaya hidup, maupun daya intelektual. ${ }^{10}$

${ }^{8}$ Said, Orientalisme ..., 143-4.

'Usaha Barat untuk mengerti Timur dibentuk sangat sistemik. Di Perancis, dibentuk "Pemuda Bahasa" tahun pada 1699. Lembaga ini didasarkan atas bahasa Semitik yang dimiliki Timur. Universitas Paris dan Institute Louis Agung menyediakan beasiswa bagi para pelajarnya dengan sponsor dari kerajaan. Di Inggris, sejak 1932 berpusat di Cambridge didirikan pusat kajian Timur Tengah. Di Amerika, Universitas Columbia bersama tujuh belas universitas lain membentuk Program Middle East Studies secara resmi dari tahun 1962-1963. Menurut George Hourani, Philip K. Hitti dan Hamilton Alexander Gibb adalah tenaga-tenaga pengajar di negara ini. Gibb adalah pemimpin Middle East Centre yang berpusat di kampus Harvard. Lihat dalam Musthafa Maufur, Orientalisme ... 39-2.

${ }^{10}$ A. Lutfi Assyaukani, "Oksidentalisme: Kajian Barat setelah Kritik Orientalisme", Jurnal Ulmul Qur'an, no. 5 dan 6 (1994). Lihat juga dalam 
Apa yang ingin dilakukan oleh oksidentalisme adalah sebuah upaya pembalikan terhadap orientalisme. Kalau selama ini Timur menjadi objek kajian orientalisme, maka dalam oksidentalisme Baratlah yang menjadi objek. Dalam menjadikan Barat sebagai objek kajian ini bukan seperti yang terjadi selama ini, yaitu mengkaji Barat dengan perspektif Barat (ru'yah al-anâ bi manz̧ĥ̀r al-anâ), melainkan mengkaji Barat dengan perspektif Timur (ru'yah al-anâ min manz̧ĥr al-âkhar), persis seperti yang dilakukan Barat terhadap Timur. Bedanya, kalau orientalisme bertujuan untuk menguasai Timur, maka oksidentalisme bertujuan untuk memahami Barat.

Karena itu, oksidentalisme akan menjadi ilmu yang netral dan obyektif. Oksidentalisme berdiri atas dasar "aku" yang objektif yang tidak memihak; ia tidak haus untuk menguasai ataupun merusak peradaban orang lain. "Aku" dalam oksidentalisme adalah "aku" yang lebih bersih dan murni dibandingkan dengan "aku" dalam orientalisme. ${ }^{11}$

Ahmad Baidowi, "Oksidentalisme Hanafi: Mengkaji Barat dengan Kaca Mata Non-Barat”, Jumal Refleksi. no. 2 ( 2003), 133.

${ }^{11}$ Ibid., 134. Hanafi mengidealkan bahwa proyek oksidentalisme akan menghasilkan. Pertama, adanya kontrol atau pembendungan atas kesadaran Eropa dari awal sampai akhir, sejak kelahiran hingga terbentuknya; kedua, adanya kesadaran bahwa kesadaran Eropa bagian dari sejarah manusia, bukan kesadaran yang berada di luar sejarah, yang tidak terjangkau oleh kritik historis; ketiga, mengembalikan tradisi dan budaya Barat ke asalnya semula dan mengakhiri apa yang dinamakan perang pemikiran dan perang budaya; keempat, menghapus mitos "budaya internasioanal" yang selalu digemborkan oleh Barat untuk menghilangkan "centris" yang bermuara pada satu bangsa; kelima, melakukan penulisan ulang terhadap sejarah dan menempatkan Barat pada proporsi yang sebenarnya; keenam, meghilangkan rasa rendah diri yang terjadi pada bangsa non Eropa ketika berhadapan dengan Eropa dan memacu diri menuju inovator; ketujuh, berupaya lebih aktif untuk membebaskan ego dari kekuasaan the other untuk dapat menjadi diri sendiri. Lihat Hassan Hanafi, Oksidentalisme: Sikap Kita terhadap Tradisi Barat, ter. Najib Bukhori (Jakarta: Paramadina, 2000), 51-9. 
Di pihak lain, penolakan yang bermotif psikologis tidak didorong oleh argumen (para penolak) yang lebih unggul daripada argumen orientalis, tetapi lebih disemangati oleh emosi keagamaan. Akibatnya, penolakan yang dilontarkan lebih mencerminkan sikap pembelaan berlebihan atas agama. Bagi mereka, agama secara keseluruhan adalah bersumber dari Tuhan dan mengandung kebenaran mutlak. Karena itu pendekatan kritis ilmiah atas agama, sebagaimana yang selalu diagungagungkan oleh orientalis, harus ditolak. Dalam pandangan mereka, pendekatan orientalis tersebut dimaksudkan untuk merongrong akidah kaum muslim. Banyak contoh buku yang berbau penolakan psikologis ini. Buku al-Islâm wa al-Mustasyriqûn (Islam dan Orientalis) karya Mushthafâ al-Sibâ̂̂, al-Istisyrâq wa alMustasyriqûn (Orientalisme dan Orientalis) karya Abû al-Jalîl Syalabî dan al-Fiker al-Islâmî wa Shillatubu bi al Isti'mâr al-Gharb̂̂ (Pemikiran Islam dan Hubungannya dengan Penjajahan Barat) karya Muhammad al-Bahî.

Dua motif tersebut, ideologis dan psikologis, baru berkembang di dunia Arab pada tahun 1960-an. Sebelum 1960an reaksi atas orientalisme lebih mengunggulkan sisi akademik ilmiah. Para intelektual Mesir biasa berdebat dengan orientalis. Universitas Mesir, seperti dilansir Novriantoni, yang sekarang menjadi Universitas Kairo, sebelum tahun 1960-an sempat menjadi tempat berkarir beberapa orientalis ternama, seperti Arthur John Arberry, Ignaz Goldziher, Joseph Schacht, dan Louis Massignon. Mereka tidak hanya melakukan respons positif secara akademik, tetapi juga memulai bibit baru oksidentalisme oleh intelektual semacam al-Thahthâwî, Thâhâ Husayn, Amîr Syâkib Arsalan, Alî Abd al-Râziq, Qâsim Amîn, dan termasuk Muhammad Abduh. Yang dimaksud bibit baru adalah respons yang alamiah ketika intelektual dunia Timur juga melakukan kajian-kajian tentang peradaban Barat sebagaimana orang Barat melakukannya terhadap Timur dengan segenap kelebihan dan 
kekurangannya. ${ }^{12}$ Era sebelum 1960-an di samping telah menunjukkan semangat keterbukaan dan ilmiah untuk memahami orang lain, juga menunjukkan bahwa dialog antarperadaban dan kebudayaan mungkin dilaksanakan dengan cara-cara yang beradab dan ilmiah.

Orientalisme telah banyak memberi sumbangan yang berarti bagi kajian ketimuran. Sepanjang zaman keemasannya pada abad XVIII dan XIX, dunia orientalisme telah melahirkan sejumlah cendekiawan simpatik yang mengabdikan sebagian besar hidupnya untuk mengkaji masalah-masalah keislaman semata dengan tujuan ilmiah murni. Jika saja bukan karena jasa-jasa mereka, karya-karya ulama muslim klasik barangkali tidak bisa ditemukan sekarang, atau barangkali akan terlupakan, atau bahkan hilang. Selain itu, di antara mereka ada yang memeluk Islam, seperti Henri Corbin, Sachiko Murata, dan William C. Chittick. ${ }^{13}$

Pendekatan yang harus dilakukan untuk melihat orientalisme adalah pendekatan kritis dalam bingkai post positivisme. Pendekatan kritis adalah seperti yang diusung oleh mazhab Frankfurt, yaitu pendekatan emansipatoris yang ditandai oleh tiga hal: pertama, bersikap kritis dan curiga atas spasio-temporal kita; kedua, berpikir secara historis, berpijak pada masyarakat dalam prosesnya yang historis; ketiga, tidak memisahkan antara teori dan praktik, tidak melepaskan fakta dari nilai semata-mata untuk mendapatkan hasil yang objektif. ${ }^{14}$ Adapun yang dimaksud post positivisme adalah meresepsi dan mempertimbangkan para pemikir post positivisme untuk dijadikan alat bantu analisis melihat orientalisme, seperti

\footnotetext{
${ }^{12}$ Novriantoni, "Mempertimbangkan Ulang Orientalisme", www.islib.com., diakses 25 Desember 2006.

${ }^{13}$ Maufur, Orientalisme..., 33.

${ }^{14}$ Budi F. Hardiman, Menuju Masyarakat Komunikatif: Ilmu, Masyarakat, Politik \& Postmodernisme menurut Juergen Habermas (Yogyakarta: Kanisius, 1993), 55-8.
} 
pendapat Feyerabend yang mengunggulkan upaya "disensus" (kebenaran-kebenaran pinggiran) yang memiliki potensi sebagai suatu kebenaran. Ia menolak klaim "konsensus", yaitu suatu upaya untuk menggeneralisasi teori dan kebenaran. Timur dalam perspektif ini berarti harus disejajarkan dengan Barat. Tidak ada istilah "pusat" dan "determinan". Upaya yang dilakukan adalah "decentering" dan "dedeterminasi". Dengan perubahan nalar semacam ini, inferioritas Timur atas Barat sudah tidak dihargai dan arogansi Barat atas Timur perlu mendapat perlawanan bersama.

\section{Kekerasan Simbolik Orientalisme}

Symbolic violence (kekerasan simbolik) adalah istilah yang digunakan oleh Pierre Bourdeu untuk menjelaskan kekerasan yang disuntikkan pada orang lain secara halus. Tentu, istilah ini digunakan untuk membedakan dengan kata "dominasi", yaitu kekerasan yang bersifat fisik, seperti penggunaan senjata, aparat kepolisian, atau tentara. Kekerasan simbolik merasuk dalam kesadaran individu secara tidak sadar, ibarat iklan rokok yang menyuguhkan kejantanan, tetapi sebenarnya membunuh jiwa. Manusia, menurut Bourdeu, dibekali dengan skema-skema yang terinternalisasi dan melaluinya mereka mempersepsi, memahami, menghargai, serta mengevaluasi realitas sosial. Bourdeu menyebut ini juga sebagai "habitus", yang dimaknai sebagai ketidaksadaran kultural, yaitu suatu pengaruh sejarah yang secara tidak sadar dianggap ilmiah. ${ }^{15}$

Kekerasan simbolik orientalisme dapat ditelisik dari pemahaman mereka tentang Timur yang dipublikasikan secara ilmiah sekaligus masif. Secara tidak sadar dunia Timur memahami mereka tidak dari interpretasi kritis diri sendiri, tetapi oleh Barat. Barat mungkin saja menjauhkan dunia Timur dan

${ }^{15}$ Bagus Takwin, "Cuplikan-Cuplikan Ideologi”, Jurnal Filsafat, no. 2 (1999), 114. 
membuat benci atas diri Timur sendiri. Orang Timur tercerabut akar kulturalnya; misalnya mereka membenci rambut hitam dan mewarnainya dengan warna pirang. Barat menyuguhkan bentuk kehebatan dan "gaul" menurut perspektif mereka. Sepak bola yang menjadi ikon Eropa merambah dunia dengan menawarkan sponsor-sponsor kelas dunia dengan realitas dunia Timur, seperti Indonesia yang tidak pernah ikut bagian dari hiruk pikuk persepakbolaan itu dan anehnya rela berjam-jam di malam hari menontoh televisi.

Umat Islam, minimal akibat dari orientalisme, mengalami tiga alienasi. Pertama, mereka teralienasi dari sejarahnya sendiri. Sejarah umat Islam harusnya dibentuk oleh mereka sendiri, tetapi Barat menawarkan sejarah yang berbeda yang kemudian dicari-cari pembenarnya dalam Islam. Tentang kasus negara demokrasi, misalnya, umat Islam bukan lah produsen dari suatu konsep. Demokrasi diandaikan sebagai pengejawantahan nilainilai Islam oleh umat Islam. Bila benar konsep demokrasi ada dalam Islam, seharusnya penggalian konsep demokrasi terus diwarnai oleh pemikiran-pemikiran umat Islam, bukan oleh para pemikir Barat. Kaum muslim teralienasi dari sejarahnya karena mereka sendiri telah terasing dari konsep sejarah yang diandaikan oleh kitab sucinya.

Kedua, umat Islam terasing dari konstitusi nalar mereka sendiri. Kajian ilmu tafsir, misalnya kurang diminati dibandingkan dengan kajian hermeneutika. Hermeneutika di-blow up sebagai kajian yang mampu mengatasi kebuntuan tafsir, daripada menggunakan ilmu tafsir yang di-upgrade. Fenomena ini diawali dari kecanggihan Barat dalam mengkonstruksi metodologi. Kecanggihan metodologi serta bungkus objektivitas ilmiah menjadi salah satu sebab daya magnetik para pelajar Timur pergi ke perguruan tinggi Barat. Nalar yang dibangun adalah nalar Barat. Implikasi lanjut, Barat dijadikan perspektif dalam melihat karya maupun aktivitas dunia Timur, padahal belum tentu apa yang dimunculkan tersebut sepi dari ide orang 
Timur. Kasus wanita boleh menjadi imam, misalnya seolah-olah adalah hasil dari cara kerja hermeneutika filosofis. Faktanya, salah satu murid pintar Imam Syafi'i, al-Muzannî dalam buku Mukhtashar al-Muzannî telah menjelaskan kebolehan menjadi imam.

Ketiga, umat Islam terasing dari bahasanya sendiri. Bahasa memiliki pandangan hidupnya sendiri. Bahasa menjadi refleksi dari apa yang diyakini. Barat mencipta umat Islam menjadi tidak percaya diri menggunakan bahasanya sendiri dalam forumforum ilmiah, bahkan di kalangan terbatas seolah-olah telah menjadi intelektual bila selalu mencampur istilah-istilah asing. Umat Islam memiliki perbendaharaan ilmu tata bahasa yang tiada tanding. Hal itu sebagaimana yang berkembang dalam khazanah keilmuan klasik, misalnya dalam Kalam yang dikembangkan Asy'ariah dan Mu'tazilah. Pada saat yang sama, penafsiran ajaran agama selalu berubah dan memunculkan pembaru-pembaru selama seratus tahun sekali. Ada titik temu antara perkembangan bahasa yang memiliki makna berbeda dengan sebelumnya dengan konteks pengguna bahasa yang dilingkupi oleh waktu dan lokalitasnya. Karena itu, bahasa sebagaimana kebudayaan, mengalami pergeseran efektif setiap seratus tahun mengikuti pergantian penggunanya. Oleh Barat, penggunaan bahasa dan simbol kultural Timur, khas Arab misalnya, seperti jenggot dianggap berwatak jahat dan membahayakan. Idiom-idiom Islam juga ditenggelamkan dalam lautan pejoratif yang sama. Celakanya, kaum muslim sendiri kemudian terpengaruh dengan cara pandang Barat itu, dan ikut memperkuat pandangan pejoratif tersebut, sehingga benar-benar teralienasi dari identitasnya sendiri.

Barat menawarkan logika oposisi biner, yes or no, ilmiah-tidak ilmiah, maju-terbelakang, dan Barat-Timur. Yang disebut pertama bersifat superior sehingga perlu membantu yang disebut belakangan. Dalam struktur sosialisme, gerak Barat ini beriringan dengan laju langkah kapitalisme. Perangkat-perangkat teknis 
dimobilisasi hanya sekedar untuk efisiensi. Bangunan pikirnya, meminjam Herbert Mercuse, adalah rasio teknologis. ${ }^{16}$ Kapitalisme kuno tidak hanya melestarikan imperialime Barat secara fisik, tetapi lebih cerdik mampu bermetamorfosa dalam kapitalisme lanjut, berupa pembentukan forum-forum dunia yang hegemonik. World Bank, PBB, dan IMF adalah sebagian dari proyek hegemoni tersebut. ${ }^{17}$

Kekerasan simbolik orientalisme berpijak pada dua hal. Pertama, ia berpijak pada penguasaan dan penaklukan wacana, baik wacana sosial maupun wacana keagamaan. Kedua, ia dikaitkan pada kepentingan teknis ideologis kapitalisme. Karena alasan ini, Barat melakukan rekayasa sosial pascahancurnya komunisme simbol kekuatan Timur dengan melawan ideologi Islam ${ }^{18}$ sekaligus memperkenalkan kosakata baru "terorisme".

16Rasionalitas teknologis adalah suatu pola pemikiran atau dasar teknik yang menekankan efisiensi, produktivitas, kelancaran, kepastian matematis, dan perhitungan untung-rugi. Rasionalitas ini sebenarnya harus dipahami sebagai rasionalitas yang bermakna ganda, yaitu satu pihak dia merupakan kritik atas proses-proses produksi, sedangkan di pihak lain merupakan alat apologis untuk mempertahankan sistem yang sudah ada. Lihat J. Sudarminta, "Kritik Marcuse terhadap Masyarakat Industri Moderen", ed. M. Sastrapratedja, Manusia Multi Dimensional, Sebuab Renungan Filsafat, (Jakarta: PT Gramedia, 1983), 130.

${ }^{17}$ Inilah yang menyebabkan kapitalisme belum bisa mati. Kaum Hippies di Jerman yang memberontak lewat perilaku nyeleneh dengan skuter butut, baju robek-robek, celana jeans, dan kalung bermanik-manik dikooptasi oleh kapitalisme modern dengan menjadikan simbol-simbol pemberontakan mereka sebagi komoditas baru. Celana jeans dijadikan mode dengan menampilkan iklan yang menggunakan publik figure tertentu, misalnya James Dean, disertai sebaris kalimat: "Jeans cap kampak, jeans pria pemberontak". Para "pemberontak tidak lagi revolusioner, malah menjadi konsumenkonsumen yang tidak kritis. Lihat dalam Donny Gahral Adian, "Ideologi dalam Perspektif Mazhab Frankfurt", Jurnal Filsafat Program Pasca Sarjana UI, no. 2 (1999), 155.

${ }^{18}$ Ideologi Islam adalah sesuatu yang menjadi angan-angan sosial dan cita-cita sosial masa depan yang diandaikan. Namun, ia bukanlah asli Islam itu sendiri. Ia hanyalah interpretasi ajaran Islam menurut kelompok tertentu 
Alienasi umat Islam akibat kekerasan simbolik dalam bahasa Althusser menyebabkan umat Islam mengalami profoundly unconcious (ketidaksadaran yang begitu mendalam). Bayangkan saja ketika Joseph Schacht dalam An Introduction to Islamic Law menjelaskan, "Hukum Islam adalah ikhtisar pemikiran Islam, manifestasi paling tipikal dari cara hidup muslim dan merupakan inti dan saripati Islam itu sendiri." 18 Pernyataan Joseph Schacht ini selalu menjadi referensi penting sebagai pintu masuk membahas hukum Islam. Para pengkaji Islam dari insider merasa canggung dan tidak percaya diri mengutip asli dari insider. Hal ini bisa dilihat dari banyak artikel yang ditulis oleh umat Islam, baik dalam jurnal maupun dalam buku bungai rampai. ${ }^{19}$ Inilah bukti paling nyata alienasi itu.

Alienasi itu tidak seperti alienasi manusia dari agama sebagaimana dipersepsi kelompok Marxian yang diletakkan dalam faktor produksi, tetapi alienasi dimaksud adalah

yang dijadikan manifesto atau petunjuk teknis strategis perjuangan. Tokoh yang sangat populer dari ideologi ini adalah Hassan al-Banna dan Sayyid Qutb yang keduanya dari Mesir. Kosakata "terorisme" seolah menjadi hantu bagi umat Islam sendiri. Suatu kata yang didoktrinasi kepada umat Islam sehingga umat Islam merasa ketakutan melabelkan diri dengan kosakata itu.

18Joseph Schacth. Pengantar Hukum Islam, ter. Moh. Said, dkk. (Jakarta: Ditbinperta, 1985), 1. Josept Schacht lahir tanggal 15 Maret 1902 dan meninggal tanggal 1 Agustus 1969 di New Jersey. Ia lahir di dataran tinggi Silesia yang dulunya masuk wilayah Jerman dan sekarang masuk wilayah Polandia. Ia berasal dari keluarga religius dan terpelajar. Ayahnya, Eduard Schacht adalah seorang penganut Katholik Roma. Tahun 1920 ia pergi ke Universitas Breslau dan Leipziq untuk mempelajari pelajaran klasik, ilmu bahasa Semit dan teologi. Schacht memiliki banyak karya, di antaranya adalah The Origin of Mubammadan Jurisprudence dan An Introduction of Islamic Law. Lihat Dedi Supriyadi, "Pemikiran Joseph Schacht (1902-1969) tentang Hukum Islam”, Jurnal Khazanah, no. 2 (2002), 348-50.

${ }^{19}$ Lihat misalnya dalam tulisan Riyanta, "Sumber Inspirasi Ushul Fiqh", Syamsul Anwar, "Pengembangan Metode Penelitian Hukum Islam", ed. Riyanta dkk., Neo Ushul Fiqh: Menuju Ijtihad Kontekstual (Yogyakarta: Fakultas Syariah Press, 2004). 
tercerabutnya kebanggaan kultural dan tradisi Timur oleh umat Islam. Suatu ketercerabutan yang kadangkala disadari, tetapi tidak mampu melakukan pembelaan karena memang seperti demikian faktanya. Umat Islam menjadi lemah karena kesadarannya telah dibonsai oleh struktur nalar Barat serta ketidakmampuan memberi antitesis seimbang. Mereka telah terkena virus false counsiousness. Lalu bagaimana umat Islam harus bersikap?

\section{Kekerasan Simbolik Orientalisme: Bagaimana Bersikap?}

Pertama-tama perlu ditegaskan bahwa upaya generalisasi adalah tindakan tidak bijak. Artinya, menganggap orientalisme pada watak negatif serta membuang kritik produktif dari mereka adalah suatu tindakan yang keluar dari semangat akademik. Tentunya tidak ingin diperuncing dikotomi radikal antara kelompok "apologis" dan "paradoks" di atas. Karena itu, sikap kritis seperti diutarakan penganut teori kritis menjadi penting. Sikap kritis berfungsi untuk memilih aspek menarik dari Islam yang justru banyak ditemukan oleh orientalis sekaligus membiarkan tergerus citra yang tak sebenarnya dari Islam. ${ }^{20}$

Pertama, harus selalu curiga. Ilmu bukan spektrum bebas nilai, ia dikonstruksi oleh manusia yang di balik otaknya menyimpan motivasi laten atau niatan gamblang dari glory, gold, dan gospel. Curiga dapat mengontrol dari penaklukan orang lain dari aspek wacana. Curiga juga mendorong untuk selalu kritis atas apa yang diterima. Namun, curiga di sini bukan berarti nihilisme. Ia adalah curiga penuh vitalitas untuk serius menemukan secercah kebenaran. Kasus teori Joseph Schacht tentang projecting back, misalnya, bisa dilihat sebagai upayanya

${ }^{20}$ Orientalis yang kemudian dikenal dengan islamisis, yang banyak menyumbang khazanah keislaman adalah seperti John L. Esposito, Karen Armstrong, Martin Lings, Annemarie Schimmel, John O. Voll, Ira M. Lapidus, Marshal GS Hodgson, Leonard Binder, dan Charles Kurtzman. 
melemahkan tradisi Islam atas kepercayaan pada orisinalitas hadis.

Schacht menjelaskan bahwa teori isnâd bukan tanda keotentikan hadis. Isnâd hanya berfungsi untuk mengamankan hadis karena dijadikan alat untuk menerima dan menolak hadis. Para ulama menjelaskan bahwa hadis berasal dari Nabi yang diperoleh dengan mendengar perkataan Nabi dan menyaksikan tindakannya dengan tanpa terputus sanad-nya dari orang-orang terpercaya.

Analisis ini membawa Schacht kepada kesimpulan yang kontroversial yang meruntuhkan pemahaman umat Islam dengan ungkapannya, "Hampir segala jenis hadis Nabi, yang difokuskan kepada hukum agama, tidak dapat dipandang sebagai hadis asli; hadis-hadis itu diletakkan sebagai sirkulasi, tidak diragukan lagi adanya motif-motif kotor, baik oleh ahli hadis semenjak pertengahan abad kedua dan seterusnya."22 Lebih lanjut, Schacht hanya menerima isnâd dari Malik-Nafi'-Ibn Umar hingga ke Nabi yang berasal dari kelompok ahli Madinah. Ketiga tokoh itu, menurutnya, adalah periwayat terbaik dari sarjana Muhammad dan paling realistik. ${ }^{23}$

M. M. Azami, yang menurut Gus Dur sebagai orang pertama yang menunjukkan bagaimana studi tentang Barat dilakukan, ${ }^{24}$ membantah teori Schacht bahwa isnâd telah digunakan secara insidental dalam sejumlah literatur di masa praperiode Islam dalam sebuah makna yang tak jelas tanpa menyentuh sasaran pemakainya. Sistem isnâd juga telah dipakai secara luas dalam periwayatan syair pra-Islam. Dalam literatur hadis, isnâd dianggap sebagai bagian dari agama. Sistem ini telah

${ }^{22}$ Ibid., 358.

23Ibid., 359.

${ }^{24}$ Abdurrahman Wahid, Oksidentalisme dalam Islam Perlu Terus Dikembangkean", dalam pidato bedah buku The History of The Qur'anic Text: From Revelation to Compilation. Ruang Anggrek lt II Istora Senayan Jakarta, Sabtu, 02 April 2005. 
dipakai secara tepat untuk mendokumentasikan literatur hadis. Contohnya adalah Dimam Ibn Thalhah datang kepada Nabi, lalu berkata kepadanya, "Muhammad, utusanmu datang dan memberitahu kami ..." Metode-metode hadis yang dipakai pada masa awal kehadiran Islam ini telah melahirkan sistem isnâd.

Tentang isnâd yang hanya dikhususkan kepada Malik-NafiIbn Umr, bagi Azami, Schacht tidak merujuk kepada karya-karya biografi yang dikarang oleh para ulama. Selain itu, Schacht sebaiknya melihat terlebih dahulu tahun kelahiran Malik dan bukan hanya tahun kematian saja. Menurut sejarah, Malik lahir tahun 93 H. Jadi, umur Malik kira-kira 20 tahun, jika tidak 24 atau 27 tahun ketika Nafi meninggal. Karena itu, Malik dan Nafi' tidak bertemu selama hidupnya. Jelas sekali bahwa Schacht kekurangan data atau fakta sejarah yang otentik. ${ }^{25}$

Lebih lanjut, Mohammad Arkoun, pemikir Islam kontemporer dari al-Jazair, ${ }^{26}$ mengkritik bahwa kajian Islam orientalisme telah mengabaikan (1) ekspresi Islam secara oral (I'expression orale de I'Islam) di kalangan bangsa-bangsa yang tidak mengenal tulisan, seperti kaum Barbar di Afrika dan bangsabangsa lain; (2) Islam yang hidup dalam praktik masyarakat, tetapi tidak ditulis dan tidak diucapkan (Les vécu non écrit et non dit), bahkan di kalangan bangsa-bangsa yang mengenal tulisan karena sebab-sebab ideologis, dominasi partai tunggal atau karena titik balik sejarah yang memaksa orang mengucapkan apa

\section{${ }^{25}$ Ibid., 384-5.}

26Lahir pada 01 Februari 1928 di Taourirt-Mimoun, Kalibia, suatu daerah pegunungan berpenduduk Berber di sebelah timur Aljazair. Karir akademiknya banyak dilakukan di Perancis pada Universitas Sorbonne. Ia menulis banyak buku seperti Ayna Huwa al-Fiker al-Islâmî, Arab Thought, alFiker al-Islâmî: Naqd wa ijtihâd dan Al-Fikr al-Islâmî: Qirâ'ah Islâmiyyah. Kebanyakan tulisan yang dikarangnya menggunakan bahasa Perancis, dan sedikit dalam bahasa Arab atau bahasa Kabilia, karena bahasa Perancis lebih mampu menampung analisisnya daripada bahasa Arab. Lihat Robby H. Abror, "Kritik Epistemologi Mohammed Arkoun", ed. Listiana Santoso dkk., Epistemologi Kiri (Yogyakarta: Ar-Ruzz, 2003), 196-8. 
yang tidak dipikirkan atau memikirkan apa yang tidak diucapkan atau ditulis; (3) ekspresi Islam yang dihayati, tetapi diucapkan (le vécu non écrit, mais parlê). Islam seperti ini lebih signifikan dan hanya bisa dikaji melalui pendekatan sosiologis; (4) mengabaikan ekspresi Islam tertulis dalam karya-karya yang dianggap nonrepresentatif (heterodoks) (les ecpressions écrites de I'Islam jugées non representatives); (5) mengabaikan sistem semiotik nonlinguistik (les systéms sémiotiques non linguistiques) yang membentuk atau berkaitan dengan lapangan keagamaan, seperti mitologi, puisi, musik, tata ruang dan waktu, urbanisme, arsitektur, seni lukis, dekorasi, perabot, busana, struktur kekerabatan, dan sistem sosial; sarjana orientalis lebih memusatkan dan mereduksi kajiannya kepada pemikiran logosentris (la pensée logocentriste) dan mempelajarinya dalam perspektif idealis dari sejarah gagasan (I'bistoire des idées).

Orientalis juga telah menyuguhkan informasi berharga dan patut diapresiasi sebagai literatur umat Islam. Penelitian Snouck Hurgronje, misalnya, memberi informasi kepada umat Islam Indonesia tentang aktivitas para muqîmin (orang Indonesia yang menetap di Mekah, seperti Nawawî al-Bantânî) sebagai orang yang mentransformasikan ajaran Islam kepada jamaah haji Indonesia di Mekah. ${ }^{27}$

Hurgronje menyatakan bahwa di awal abad XIX di Mekah ada komunitas Jawa. Nawawi adalah guru sarjana yang terkemuka di kalangan komunitas Jawa tersebut. Dia enggan untuk mengajar di Universitas al-Haram pada saat banyak ulama

${ }^{27}$ Hurgronje menjelaskan bahwa pembatasan jamaah haji serta pengetatan untuk melaksanakan haji tidak penting karena yang perlu diperhatikan adalah peran serta para muqîmin di Mekah. Mereka memberi jalur transmisi pengetahuan sehingga melakukan pemberontakan setelah para haji pulang dari Tanah Suci. Akibat saran ini, pemerintah Belanda tidak lagi melakukan tindakan keras kepada jamaah haji. Lihat Asep Muhammad Iqbal, Yabudi \& Nasrani dalam al-Qur'an: Hubungan Antar Agama Menurut Syaikh Nawawi Banten (Jakarta: Teraju, 224), 17-8. 
Jawa mengajar di al-Haram, seperti Syekh Zainuddin Sumbawa. Dia enggan dikarenakan sikap zuhud dan kesederhanaanya serta lebih senang untuk melayani para murid-murid dari tanah melayu yang memang belum mengerti bahasa Arab secara baik. Dia juga dikenal memiliki watak keras atas kolonialisme dan berperan penting mentransmisikan pentingnya Indonesia merdeka dari penjajah. ${ }^{28}$

Masih banyak informasi mencakup sejarah, pemikiran, tasawuf, maupun hukum Islam dari orientalis yang berharga. Sikap bijak intelektual serta kearifan akademik yang diawali dari curiga adalah yang diharapkan.

Kedua, menyemarakan dialog ilmiah. Upaya ini lebih terbuka untuk jujur secara ilmiah. Penentangan yang bersifat ideologis dan psikologis di atas tidak produktif untuk umat Islam karena membiarkan dunia Timur, umat Islam khususnya, menjadi objek dan hanya memberi respons perlawanan wujud kekalahan dan kelemahan. Upaya konstruktif dilakukan untuk orientalisme adalah lawan fakta dan analisis. Umat Islam tidak perlu takut atau bahkan khawatir Islam akan runtuh.

Bila disepakati bahwa kebenaran ilmiah dikategorikan pada kebenaran pragmatik, korespondensi, dan koherensi, maka dialog dilakukan sebagai ajang pembuktian baik melalui verifikasi maupun falsifikasi untuk tiga kebenaran tersebut. Contoh kritik yang dimunculkan Azami terhadap pendapat Schacht adalah bukti bahwa Schacht tidak memenuhi kualifikasi kebenaran korespondesi. Secara perlahan bangunan teori tersebut hanya akan eksis dalam kertas dan tidak lagi dibaca orang. Di sisi lain, penelitian Hurgronje bersesuaian dengan kebenaran korespondensi. Yang benar harus diakui benar dan yang salah harus diungkap salah.

Dialog ilmiah merupakan wujud keberanian umat Islam hidup dalam masyarakat plural. Dunia tidak lagi homogen,

${ }^{28}$ Ibid., 56-7. 
tetapi, meminjam Lyotard, bersifat paralogis. Setiap pemikiran layak untuk dihadirkan dan pada saat yang sama ia juga pantas untuk disalahkan. Meletakkan orientalisme bagian dari kreasi intelektual berarti meletakkan kajian orientalisme sebagai hasil interpretasi atas sesuatu, laiknya interpretasi yang bisa saja keliru dan mungkin juga benar.

Dialog ilmiah secara internal akan menumbuhkan sikap umat Islam yang progresif dan maju, setelah beberapa abad umat Islam dilanda kemunduran ilmiah. Umat Islam lebih dikuasai epistemologi 'irfânî (orientasi batin dan intuisi) dan epistemologi bayânî (orientasi teks keagamaan, al-Qur'an dan hadis). Semarak ilmiah sebagaimana tradisi intelektual Islam masa lalu diharapkan bisa muncul kembali. Dengan demikian, debat atas temuan orientalisme seharusnya lebih menukik pada penelusuran fakta sosial, budaya dan politik, dan keagamaan daripada kebencian teologis, ideologis, maupun psikologis. Secara eksternal, dialog demikian akan menghilangkan ingatan sosial pejoratif dan stigmatik atas umat Islam atau dunia Timur yang rendah, terbelakang, penuh mitos, dan kumuh. Umat Islam tidak saja dihargai secara teologis, tetapi juga secara intelektual dan aksi sosial.

Ketiga, memunculkan semangat disensus bukan konsensus. Semangat disensus adalah semangat yang memberi warna pada konstitusi nalar bahwa setiap teori memiliki tempat untuk menjadi benar. Teori sempalan atau teori pinggiran layak untuk memiliki posisi. Disensus berarti menolak klaim-klaim universalisme dan homogenisasi ide. Klaim Barat lebih unggul, lebih maju, dan lebih modern berarti tidak dihargai lagi dalam semangat disensus. Inilah lawan dari konsensus yang berniat menyatukan serta melanggengkan oposisi biner. Konsensus memotivasi sebuah rezim pemikiran untuk totaliter dan menindas. Karenanya, semangat konsensus layak untuk ditolak. Barat menjadi totaliter karena ia menganggap selain dirinya harus di-Baratkan. Barat menjadi pusat sedangkan yang lain adalah 
pinggiran. Dalam disensus, semua adalah pusat dan tidak ada wilayah pinggir sehingga tidak boleh ada yang menguasai pihak lain.

Di panggung semangat disensus tidak ada lagi dominasi. Barat tidak boleh lebih dominan. Orientalisme tidak boleh menguasai wacana. Setiap gagasan dan ide dapat hidup dan bertanding dalam dunia keragaman, paralel satu sama lain. Bagi Lyotard, pemikir post-positivis, yang kini tinggal adalah intensifikasi dinamika usaha yang tak habis-habisnya dan tak henti-hentinya untuk mencari kebaruan, menghindari klaimklaim universal, dan berangkat dari persoalan-persoalan lokal. ${ }^{29}$ Segala wacana berhak atas kebenarannya masing-masing. Kekerasan simbolik orientalisme, sinergi dengan ide disensus, tidak boleh lagi muncul. Yang sebaiknya dilakukan adalah mempersiapkan diri menerima perbedaan bukan persamaan universal.

Semangat disensus, seperti semarak dialog ilmiah, akan memberi keuntungan ganda bagi dunia Timur, khususnya Islam. Pertama, dari sisi internal, umat Islam tidak lagi berebut kebenaran interpretasi ajaran antarberbagai faksi pemikiran. Umat Islam tambah dewasa dalam menghadapi perbedaan seperti yang telah dicontohkan oleh para imam mazhab. "Perbedaan umatku adalah rahmat" hadir dalam masyarakat disensus bukan konsensus.

Umat Islam perlu menata aspek lain di luar aspek teologis, tentu setelah teologi diselesaikan secara sadar bahwa memang tidak mungkin sependapat. Kedua, umat Islam menjadi avant garde bagi gerakan social cultural movement, sebuah gerakan sosial kultural untuk menciptakan tatanan dunia yang damai bebas dari penindasan dan eksploitasi. Dominasi fisik telah berakhir dengan semangat nation state, tetapi penindasan terselubung, seperti proyek orientalisme dalam konstruk kekerasan simbolik berupa

${ }^{29}$ Takwin, “Cuplikan...”, 114. 
gagasan, wacana, serta interperatasi sejarah dan ajaran agama, masih terus dilestarikan. Agenda seterusnya dari gerakan itu adalah umat Islam menyadari dan terus menyebarkan bahaya dominasi dan kekerasan simbolik tersebut. Orientalisme dan gerakan Barat lainnya perlu disikapi secara proporsional, kritis, dan berkesadaran.

Umat Islam harus cerdas menangkap perkembangan ilmu pengetahuan serta kepekaan intuitif untuk melakukan kajian yang tidak hanya dari dan untuk umat Islam tetapi juga tentang dan untuk Barat. Hanafi mengawali hal yang baik dengan kajian oksidentalisme. Ia berambisi untuk megembalikan Barat pada batas-batas yang wajar dan tidak merambah ke mana-mana. Ia juga ingin melihat Barat dari kacamata Islam (Timur) setelah sebelumnya Barat melihat Timur dari kaca mata Barat. ${ }^{30}$

Umat Islam juga perlu digairahkan untuk melihat Timur dari kacamata Timur serta melihat Barat dari kacamata Timur. Melihat Timur dari kacamata Timur adalah melakukan kritik internal untuk kebaikan dan kemajuan, sedangkan melihat Barat dari kacamata Timur dilakukan untuk keseimbangan dalam perbincangan wacana dan leburnya dominasi pemikiran.

Umat Islam (Timur) perlu cerdas menangkap ilmu pengetahuan. Umat Islam tidak boleh tertinggal kecanggihan teknologinya sehingga pendidikan harus terus digalakkan. Mereka perlu juga cerdas secara intuitif agar tidak mengalami kekeringan spiritual. Barat menindas dan totaliter disebabkan oleh budaya positivistik tanpa aspek transendental.

Proyek ilmu pengetahuan yang awalnya diarahkan untuk proses pemanusiaan manusia justru menempatkan manusia pada proses dehumanisasi. Dengan demikian, orientalisme dapat didudukkan semestinya tanpa kebencian sekaligus tanpa resepsi berlebihan.

${ }^{30}$ Hanafi, Oksidentalisme..., 51-9. 


\section{Catatan Akhir}

Mengurung diri secara apologis dan paradoksal atas orientalisme bukan karakter yang diinginkan oleh Islam. Andai kata matahari dikhususkan buat umat Islam, maka nonmuslim tentu akan gelap tanpa cahaya. Namun, faktanya tidak seperti demikian. Ayat-ayat Tuhan berupa hamparan realitas dan wilayah bebas untuk berbagai macam kepercayaan. Kebenaran bisa mungkin datang dari mereka yang kadangkala secara teologis bukan umat Muhammad.

Orientalisme memiliki potensi benar dan salah. Bila benar, secara jujur umat Islam harus menerimanya. Sebaliknya, bila salah, kritik perlu dihadirkan. Namun, untuk menunjukkan benar dan salah, umat Islam perlu dialog ilmiah dengan mempresentasikan fakta serta argumen yang bisa diterima. Penentangan tidak akan pernah konstruktif bila hanya sekedar bermotif ideologis atau hanya psikologis.

Kekerasan simbolik berupa dominasi dan hegemoni wacana orientalisme perlu disadari kehadirannya. Tentu setelah umat Islam bersikap bijak di atas (bisa benar dan bisa salah). Bila ia telah merezim, maka bahayanya lebih besar dari dominasi fisik. Ia akan menjauhkan dari identitas umat Islam sendiri. Kekerasan simbolik orientalisme sebaiknya dihadapi dengan menghadirkan wacana seimbang oleh umat Islam dengan membekali diri berupa kecerdasan ilmu pengetahuan serta kecerdasan intuitif. ${ }^{31}$ Di panggung disensus wilayah paralogis ini, kekerasan simbolik orientalisme tidak boleh memiliki tempat. Orientalisme harus disuguhkan sejajar dengan "isme-isme" lain.

${ }^{31}$ Bukan wacana tandingan karena wacana tandingan berpotensi untuk menindas pula bila wacana tandingan itu menang dan berkuasa. Ibarat gerakan revolusioner kaum proletar yang bisa berubah menjadi kelompok borjuis dan menindas jua. 


\section{Daftar Pustaka}

Abdurrahman Wahid, "Oksidentalisme dalam Islam Perlu Terus Dikembangkan" dalam Pidato bedah buku The History of The Qur'anic Text: From Revelation to Compilation. Ruang Anggrek lt II Istora Senayan Jakarta, Sabtu, 02 April 2005, Jam 10.00 WIB.

Achmad Jainuri, Ideologi Kaum Reformis (Surabaya: lpam, 2002).

Ahmad Baidowi, "Oksidentalisme Hanafi: Mengkaji Barat dengan Kaca Mata Non-Barat”, Jurnal Refleksi, no. 2 (2003).

Asep Muhammad Iqbal, Yahudi \& Nasrani dalam al-Qur'an:

Hubungan Antar Agama Menurut Syaikb Nawawi Banten (Jakarta: Teraju, 2004).

Bagus Takwin, "Cuplikan-Cuplikan Ideologi”, Jurnal Filsafat, no. 2 (1999).

Budi F. Hardiman, Menuju Masyarakat Komunikatif: Ilmu, Masyarakat, Politik \& Postmodernisme Menurut Juergen Habermas (Yogyakarta: Kanisius, 1993).

Dedi Supriyadi, "Pemikiran Joseph Schacht (1902-1969) tentang Hukum Islam", Jurnal Khazanah, no. 2, (Juli-Desember 2002).

Donny Gahral Adian, "Ideologi dalam Perspektif Mazhab Frankfurt", Jurnal Filsafat Program Pasca Sarjana UI, no. 2 (1999).

Edward W. Said, Orientalisme, ter. Asep Hikmat (Bandung: Pustaka, 2001).

Hassan Hanafi, Oksidentalisme: Sikap Kita terhadap Tradisi Barat, ter. Najib Bukhori (Jakarta: Paramadina, 2000).

J. Sudarminta, "Kritik Marcuse terhadap Masyarakat Industri Moderen”, ed. M. Sastrapratedja, Manusia Multi Dimensional: Sebuab Renungan Filsafat (Jakarta: PT Gramedia, 1983).

Joseph Schacht, Pengantar Hukum Islam, ter. Moh. Said dkk. (Jakarta: Ditbinperta, 1985).

Listiana Santoso dkk., Epistemologi Kiri (Yogyakarta: Ar-Ruzz, 2003). 
Lutfi Assyaukani, "Oksidentalisme: Kajian Barat setelah Kritik Orientalisme", Jurnal Ulmul Qur'an, no. 5 dan 6 (1994).

M. Amien Rais, Cakrawala Islam (Bandung: Mizan, 1986).

Maryam Jamilah, Islam dan Orientalisme: Sebuah Kajian Analitik, ter. Machnun Husein (Jakarta: Rajawali Press, 1994).

Mustolah Maufur, Orientalisme: Serbuan Ideologis dan Intelektual (Jakarta: Pustaka al-Kautsar, 1995).

Novriantoni, "Mempertimbangkan Ulang Orientalisme", wnw.islib.com., diakses 25 Desember 2006.

Riyanta dkk., Neo Ushul Fiqh: Menuju Ijtihad Kontekstual (Yogyakarta: Fakultas Syariah Press, 2004). 